\title{
Geochemistry of Ordovician black shales at Meductic, southern Miramichi Highlands, New Brunswick
}

\author{
James F. Hennessy* and David J. Mossman \\ Department of Physics, Engineering and Geoscience, Mount Allison University, \\ Sackville, New Brunswick E0A 3C0, Canada
}

Date Received July 19, 1995

Date Accepted March 4, 1996

\begin{abstract}
The geochemistry of black shales is useful for identifying geological events such as anoxia, for predicting the proximity of submarine hydrothermal springs and associated mineral deposits, and for indicating the existence of mineral deposits in precursor terrains. In the Miramichi Highlands of New Brunswick, large massive sulfide deposits occur in a mid-Ordovician (Llanvirnian) sequence of felsic volcanic and sedimentary rocks of the Tetagouche Group, disconformably overlying relatively monotonous quartzose wacke and grey-green shale of the Miramichi Group. Black shales commonly occur at the boundary between the Miramichi and Tetagouche groups, and in some areas such as at Meductic in the southern Miramichi Highlands, they display high heavy metal values in common with Scandinavian-Caledonide black shales. Like the massive sulphide deposits, the Meductic metalliferous black shales were deposited in a back-arc basin associated with an island-arc system formed during the closing of the proto-Atlantic Ocean and the onset of the Taconian orogeny.

The average Meductic black shale, as deduced from the Bright Eye Brook Formation at the base of the Tetagouche Group, shows high values of $\mathrm{V}$ and $\mathrm{Ba}$, moderate enrichment in $\mathrm{Nb}, \mathrm{Th}, \mathrm{Pb}, \mathrm{Ti}$, and $\mathrm{Cr}$, and depletion in $\mathrm{Sr}, \mathrm{Cu}$ and Ni compared to black shale USGS standard SDO-1. Total organic carbon is well above the minimum value for a carbonaceous shale, the highest value $(2.35 \%)$ corresponding to highest $\mathrm{V}(3016 \mathrm{ppm})$ and highest $\mathrm{Ba}(16,173$ ppm). $\mathrm{CaO}, \mathrm{Fe}_{2} \mathrm{O}_{3}$ and $\mathrm{MnO}$ contents are low, and $\mathrm{SiO}_{2}, \mathrm{~K}_{2} \mathrm{O}$ and $\mathrm{P}_{2} \mathrm{O}_{5}$ contents are relatively high compared to the standard. Chondrite-normalized REE patterns show elevated LREE, fairly flat HREE signatures, a negative Eu anomaly and a slightly positive $\mathrm{Ce}$ anomaly. These features are characteristic of marine volcanological detrital input rather than a hydrothermal regime. Correlation of high $\mathrm{V}$ with $\mathrm{Ba}$ indicates that conditions were favourable for deposition of both metals. It is postulated that early deposition in an oxic environment (higher than normal $\mathrm{MnO}$ ) was succeeded by gradual stagnation (increasing levels of $\mathrm{V}$ ). Concomitant enrichment in Ba under anoxic conditions was linked to a regime of elevated heat flow. This scenario is compatible with the record of sea level fluctuations during the early Palaeozoic.
\end{abstract}

L'analyse géochimique des schistes noirs permet de déceler des phénomènes géologiques comme l'anoxie, qui annonce la proximité de sources hydrothermales sous-marines et de gîtes minéraux connexes et qui révèle l'existence de gîtes minéraux dans des terrains précurseurs. Dans les hautes terres de Miramichi, au NouveauBrunswick, on relève des gisements de sulfures massifs importants dans une séquence de l'Ordovicien moyen (Llanvirnien) de roches sédimentaires et volcanofelsiques du groupe de Tetagouche qui recouvrent de façon discordante des wackes quartzeuses relativement monotones et des schistes gris-vert du groupe de Miramichi. On trouve couramment des schistes noirs le long de la frontière séparant les groupes de Miramichi et de Tetagouche; de plus, dans certains secteurs, comme celui de Meductic, dans le sud des hautes terres de Miramichi, les schistes noirs affichent, en commun avec des schistes noirs scandinaviens-calédoniens, des valeurs élevées de métaux lourds. À l'instar des gisements de sulfures massifs, les schistes noirs métallifères de Meductic se sont déposés dans des bassins arrière-arcs associés à un système d'arcs insulaires formé lors de la fermeture de l'océan proto-atlantique et au début de l'orogenèse taconique.

Les schistes noirs de Meductic moyens, d'après ce qu'on en déduit de la Formation de Bright Eye Brook à la base du groupe de Tetagouche, affichent des valeurs élevées de $\mathrm{V}$ et de $\mathrm{Ba}$, un enrichissement moyen en $\mathrm{Nb}$, Th, $\mathrm{Pb}$, Ti et $\mathrm{Cr}$, ainsi qu'une réduction de $\mathrm{Sr}$, de $\mathrm{Cu}$ et de $\mathrm{Ni}$, comparativement à la norme SDO-1 du USGS. Le carbone organique total se situe bien au-dessus de la valeur minimale d'un schiste charbonneux, la valeur la plus élevée $(2,35 \%)$ correspondant aux teneurs les plus élevées en V $(3016 \mathrm{mg} / \mathrm{kg})$ et en Ba $(16173 \mathrm{mg} / \mathrm{kg})$. Les teneurs en $\mathrm{CaO}, \mathrm{Fe}_{2} \mathrm{O}_{3}$ et en $\mathrm{MnO}$ sont basses et celles en $\mathrm{SiO}_{2}, \mathrm{~K}_{2} \mathrm{O}$ et $\mathrm{P}_{2} \mathrm{O}_{5}$ sont relativement élevées comparativement aux teneurs normales. Les modèles d'ETR réduits en chondrites affichent des quantités élevées d'éléments de terres rares légers, des signatures d'éléments de terres rares lourds passablement uniformes, une anomalie négative d'Eu et une anomalie légèrement positive de $\mathrm{Ce}$. Ces traits sont caractéristiques d'un apport détritique volcanologique marin plutôt que d'un régime hydrothermal. La corrélation de valeurs élevées de $\mathrm{V}$ et de $\mathrm{B}$ révèle que les conditions étaient propices à la sédimentation des deux métaux. On suppose qu'une sédimentation précoce dans un milieu oxique (présence de $\mathrm{MnO}$ supérieure à la normale) a été suivie par une stagnation graduelle (niveaux croissants de V). On a relié l'enrichissement concomitant en Ba dans des conditions anoxiques à un régime de flux thermique élevé. Ce scénario est compatible avec les fluctuations du niveau de la mer enregistrées au cours du Paléozolque inférieur.

[Traduit par la rédaction]

-Present Address: Northeast Exploration Services Limited, 875 St. Peter Avenue, Bathurst,

New Brunswick B2A 2Z1, Canada

Atlantic Geology

32, 233-245 (1996)

0843-5561/96/030233-13\$2.95/0 


\section{INTRODUCTION}

The widely accepted standard definition of black shale is “.... dark-colored (grey or black), fine-grained (silt sized or finer), laminated sedimentary rock that generally is argillaceous and contains appreciable carbon $(>0.5 \mathrm{wt}$. \%)" (Huyck, 1990). The statement that a minor metal is enriched in a sedimentary rock has meaning only with reference to some concentration taken as a standard. Accordingly, Huyck (1990) defined metalliferous black shale as ".... black shale that is enriched in any given metal by a factor of $2 \mathrm{X}$ (except for beryllium, cobalt, molybdenum and uranium for which $1 \mathrm{X}$ is sufficient) relative to the U.S. Geochemical Standard SD01." Extensive literature exists on black shales and on metalliferous black shales (see Arthur and Sageman, 1994) and these rocks continue to receive a great amount of attention because of their growing relevance as mineral and energy resources (Shultz, 1991) and their potential role as environmental hazards (Reichenbach, 1993). Metalliferous black shales have been documented in Cambro-Ordovician units at Saint John in southern New Brunswick and at Meductic in central New Brunswick (Fyffe and Pickerill, 1993; Fyffe, 1994) (Fig. 1).

In northeastern New Brunswick, large Brunswick-type massive sulfide deposits near Bathurst occur in a Llanvirnian sequence of felsic volcanic and sedimentary rocks of the Tetagouche Group, disconformably to conformably overlying relatively monotonous quartzose wackes and greyishgreen shales of the Miramichi Group (Fyffe, 1990, 1994). Black shales generally occur at the boundary between the Miramichi and Tetagouche groups (van Staal and Fyffe, 1991). These black shales are apparently akin to the ScandinavianCaledonide black shales, some of which display high metal values (Neuman, 1984). Like the base metal deposits of the Bathurst Mining camp, the black shales are believed to have been deposited in a back-arc basin associated with an island-arc system formed during the closing of the proto-Atlantic Ocean and the onset of the Taconian orogeny (Fyffe,

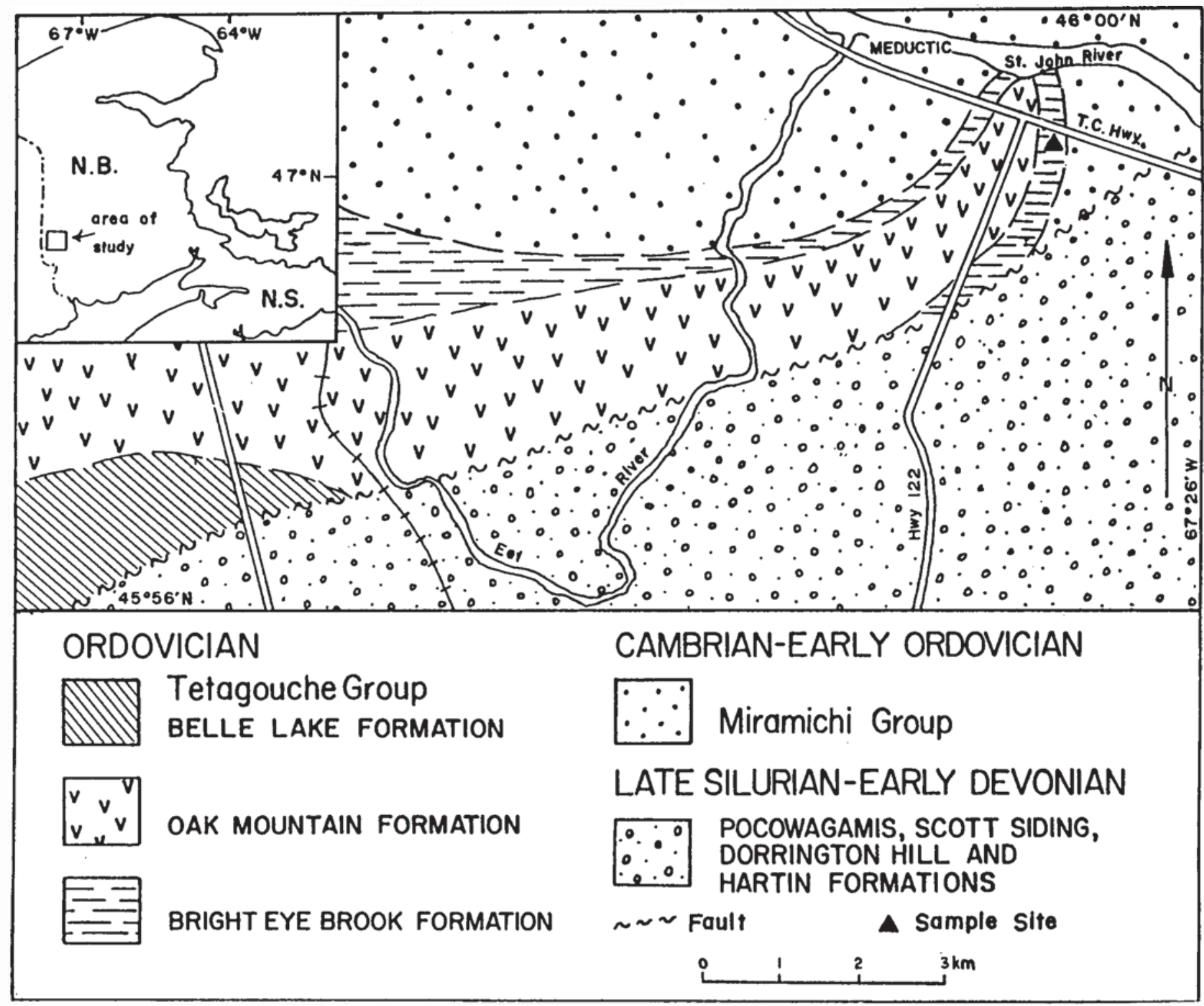

Fig. 1. Location map and general geology of the black shale locality at Meductic, New Brunswick (modified after Fyffe and Pickerill, 1993). 
1994; Fyffe and Pickerill, 1993; Goodfellow et al., 1995; Lentz and Goodfellow, 1995).

The focus of the present report is the geochemistry and mineralogy of black shales in the Bright Eye Brook Formation at Meductic (Fig. 1). In particular, an effort is made to identify any systematic changes in chemostratigraphy along a measured section crossing the boundaries between the Miramichi Group and the overlying Bright Eye Brook and Oak Mountain formations of the Tetagouche Group.

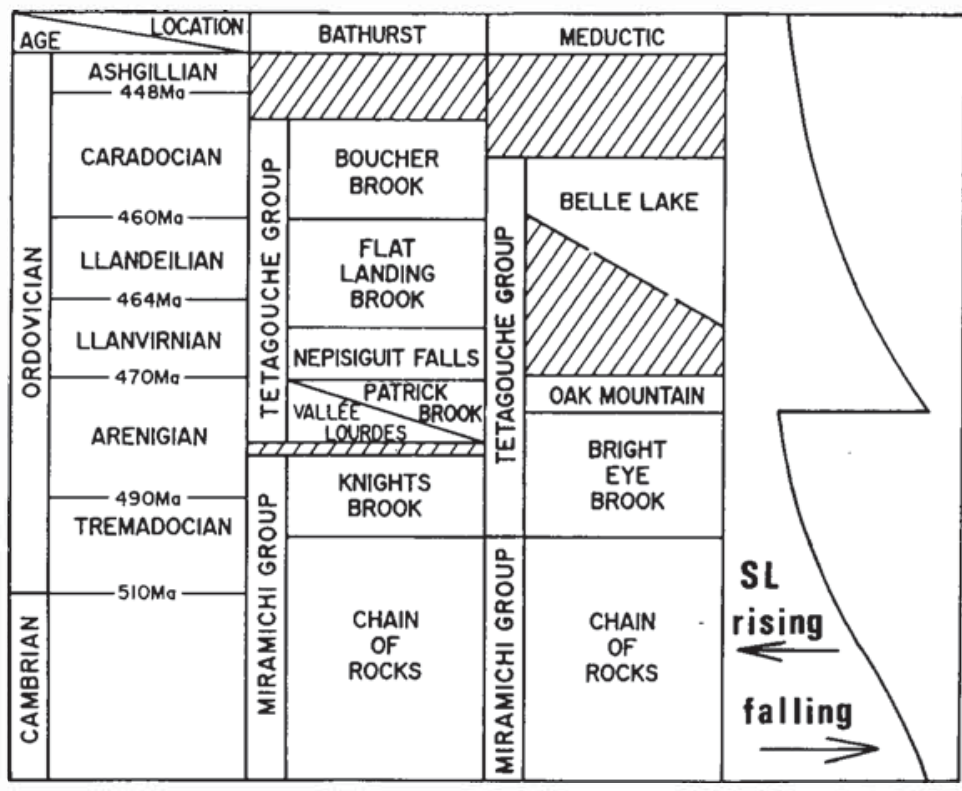

Fig. 2. Stratigraphic columns for Cambrian to Ordovician rocks in the Bathurst area of the northern Miramichi Highlands, the Meductic area of the southwestern Miramichi Highlands, and the Belledune area of the Chaleur Uplands (after Fyffe, 1994).

\section{Geological Setting}

Black shale and siltstone of the Bright Eye Brook Formation (Fig. 2) are identified as the basal unit of the Tetagouche Group in the Meductic area (Fyffe and Pickerill, 1993). This unit conformably overlies quartzose turbidites correlated with the Chain of Rocks Formation of the Miramichi Group in northeastern New Brunswick. The Bright Eye Brook Formation is conformably overlain by a sequence of banded iron formation, felsic pyroclastic rocks and andesitic flows interbedded with red ferromanganiferous slate of the Oak Mountain Formation (Fyffe, 1982; Fyffe et al., 1983; Venugopal, 1979) and clastic turbidites of the Belle Lake Formation, all of which are contained in the Tetagouche Group (van Staal and Fyffe, 1991; Fyffe et al., 1990; Fyffe, 1994). An age of mid to late Arenig is indicated for the Bright Eye Brook Formation on the basis of fossil evidence (Fyffe et al., 1983). This time frame corresponds to a condensed section encompassing the time of deposition of the Knights Brook Formation and possibly also the Vallée Lourdes and Patrick Brook formations of northeastern New Brunswick. Numerous mafic dykes of Devonian age have intruded the area (Gariepy and David, 1988).

\section{SAMPLE DESCRIPTION AND ANALYSIS}

Thirteen hand samples, MD-1 to 13 , were collected over an $85 \mathrm{~m}$ section (see Fig. 3) on the south side of the TransCanada Highway, $2 \mathrm{~km}$ southeast of Meductic. Sample MD1 , probably a distal turbidite, was collected from the top of the Miramichi Group; samples MD-2 through MD-12 are black shales collected along a $50 \mathrm{~m}$ thick stratigraphic section, within which the Bright Eye Brook Formation is rep-

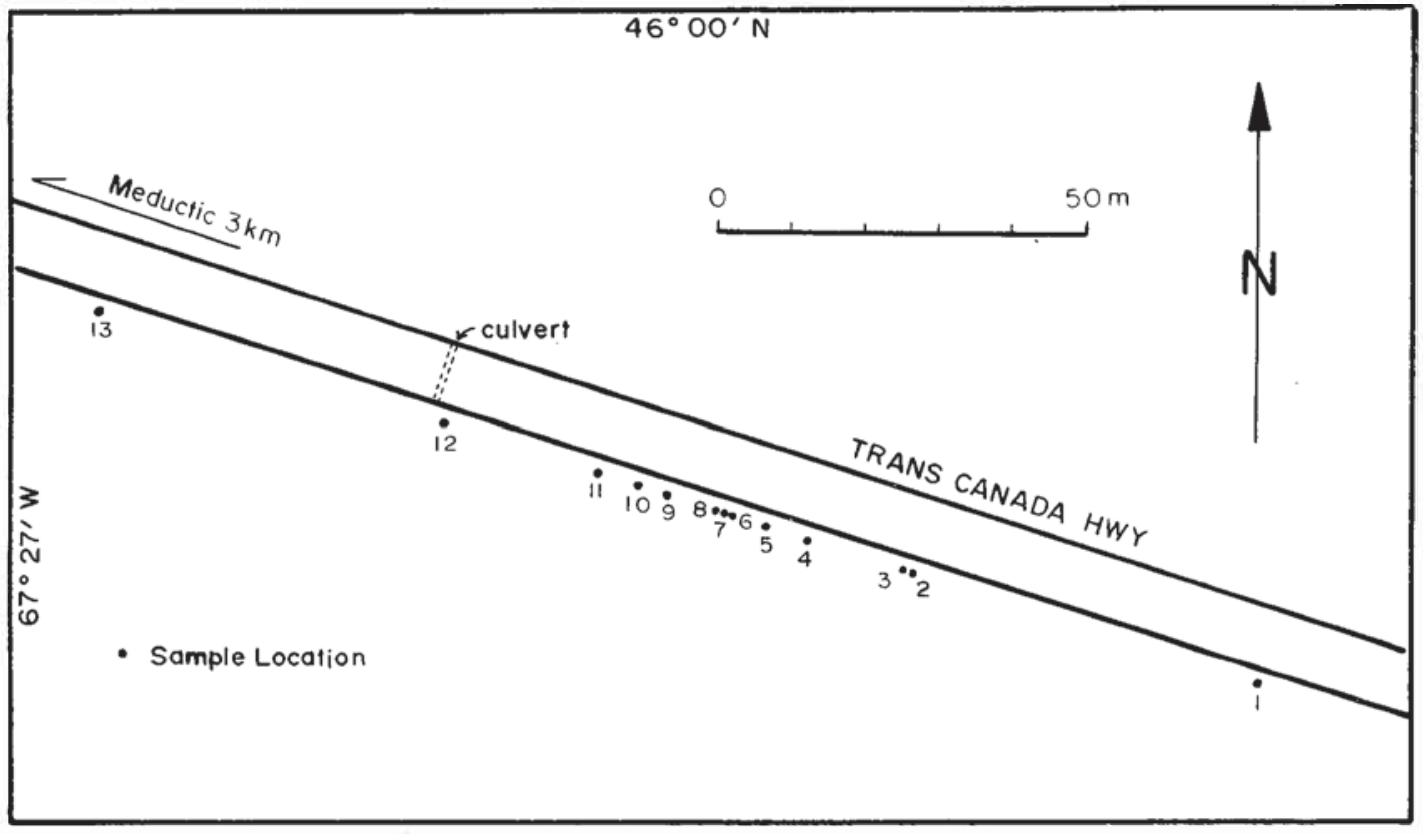

Fig. 3. Sketch map showing sample sites MD-1 to MD-13 along a measured stratigraphic section across the boundaries of the Miramichi Group/Bright Eye Brook Formation/Oak Mountain Formation on the south side of the Trans-Canada Highway, 2 km southeast of Meductic, New Brunswick. Strata strike approximately east-west and dip $80^{\circ}$ north. 
resented by samples MD-5 through MD-11. Sample MD13, a magnetic purple-grey siltstone, was collected about $35 \mathrm{~m}$ above the black shales within the Oak Mountain Formation. Petrographic descriptions of selected representative samples are given in Appendix A (see also Hennessy, 1995).

Major elements (Table 1) were determined by X-ray fluorescence (XRF) and other trace elements (Table 2a) and rare earth elements (Table $2 b$ ) by neutron activation (NAA) analysis at the Regional Analytical Laboratory, St. Mary's University. Linear regression analysis was done on all major and trace elements (Hennessy, 1995).

Activation Laboratories, Ancaster, Ontario, determined carbon and sulfur using a LECO combustion and IR detection unit, model CS-344; graphitic carbon was determined by leaching with $15 \% \mathrm{HCl}$ to drive off $\mathrm{CO}_{2}$ followed by ignition at $600^{\circ} \mathrm{C}$ to eliminate organic carbon. Total organic carbon (TOC) was determined by difference after subtracting organic, graphitic and $\mathrm{CO}_{2}$ carbons (Table 3 ). Table 4 shows the mineralogy of selected samples as determined by $\mathrm{X}$-ray diffraction.

\section{Results}

As shown in Figure 4a to $\mathrm{g}$, the following correlations are most notable (correlation coefficients reported in brackets): strong, positive correlation between $\mathrm{Ba}$ and $\mathrm{Rb}(0.91)$, $\mathrm{Th}(0.85)$, and $\mathrm{Zr}(0.84)$ (Fig. 4a); good positive correlation between $\mathrm{Rb}$ and $\mathrm{K}_{2} \mathrm{O}(0.88)$ (Fig. $4 \mathrm{~b}$ ); moderate positive correlation between $\mathrm{Sr}$ and $\mathrm{Zr}(0.83)$ (Fig. 4c); good positive correlation between $\mathrm{Zr}$ and $\mathrm{TiO}_{2}(0.93), \mathrm{Nb}(0.83)$ and $\mathrm{Cr}$ (0.82) (Fig. 4d); good negative correlation between $\mathrm{Ni}$ and $\mathrm{Rb}(0.89)$ and $\mathrm{Ba}(0.83)$, and positive correlation between $\mathrm{Ni}$ and $\mathrm{Zn}(0.89)$ and $\mathrm{Fe}_{2} \mathrm{O}_{3}(0.85)$ (Fig. 4e); moderate positive correlation between $\mathrm{V}$ and $\mathrm{Ba}(0.83)$ and $\mathrm{Rb}$ (0.82) (Fig. 4f); strong negative correlation between $\mathrm{SiO}_{2}$ and $\mathrm{Fe}_{2} \mathrm{O}_{3}(0.92)$ (Fig. $4 \mathrm{~g}$ ). In Figure $4 \mathrm{f}$, the $\mathrm{MnO}$ contents highlight a recurrent contrast in the geochemistry among the Meductic samples.

The relatively elevated content of $\mathrm{MnO}$ (see Fig. $4 \mathrm{f}$ ) in samples MD-1 to MD-4 and in MD-12 and MD-13 provides good reason to suspect that only samples MD-5 through MD11 belong to the Bright Eye Brook Formation. It may be, therefore, that this chemical contrast could be employed to more rigorously define the boundaries between the Bright Eye Brook Formation, the underlying Miramichi Group, and the overlying Oak Mountain Formation (L.R. Fyffe, written communication, 1995). In light of this possibility the average chemical composition of samples MD-5 to MD-11 (Fig. 4 ) is taken as representative of Meductic black shale.

Compared to black shale standard SDO-1 (Fig. 5), the average Meductic black shale is enriched in $\mathrm{SiO}_{2}, \mathrm{Al}_{2} \mathrm{O}_{3}$, $\mathrm{K}_{2} \mathrm{O}, \mathrm{TiO}_{2}$ and $\mathrm{P}_{2} \mathrm{O}_{5}$. There is a distinct depletion in $\mathrm{Fe}_{2} \mathrm{O}_{3}$, $\mathrm{CaO}$, and to a lesser extent, $\mathrm{MnO}$. Trace element composition of average Meductic black shale is likewise elevated (Fig. 6) to an extent which, by definition, marks it as a metalliferous black shale. Most notable is the order-of-magnitude enrichment in $\mathrm{Ba}$ and $\mathrm{V}$ compared to the standard.

Contrasts in average REE composition (Fig. 7) of Meductic black shale with those of SDO-1 and post-Archean average Australian shale (PAAS) (Taylor and McLennan, 1985) include relatively high abundance of REE in the Meductic samples compared to the standards, enrichment in LREE, relatively flat HREE, perceptible negative Eu anomaly, and slightly positive $\mathrm{Ce}$ anomaly.

\section{Discussion}

The Meductic black shales are considered coeval with the lower Tetagouche Group of northeastern New Brunswick, which has been interpreted as an island-arc system formed on the northwestern margin of the Avalonian Platform during the Cambrian (Fyffe, 1994; McBride, 1976; Whitehead and Goodfellow, 1977). Dostal (1989) noted that Ordovician sequences from the Meductic and Bathurst areas have similar lithology and stratigraphy, including comparable ages and the presence of iron formation and graptolite-bearing shale (cf. Fyffe et al., 1983). Dostal (1989), therefore, concluded that they may both be part of a single Ordovician island-arc system. On a $\mathrm{La} / \mathrm{Yb}$ vs $\mathrm{Th} / \mathrm{Yb}$ plot for mafic rocks of the Tetagouche Group from the Meductic area his sample ratios fall within the range of modern-arc related mafic lavas. Two selected samples of Meductic black shale fall in this same area (Fig. 8), suggesting that the relative levels of $\mathrm{La}$, $\mathrm{Th}$ and $\mathrm{Yb}$ in these shales may be in large measure the result of weathering and transportation from older arc-related mafic lavas. Supporting this inference is the low average $\mathrm{Al} / \mathrm{Ti}$ (17.5) of the Meductic shales which indicates a significant volcanic imput, compatible with deposition proximal to an island-arc system.

Another important clue to the environment of deposition is the negative Eu anomaly of the Meductic shales (Fig. 6). According to Taylor and McLennan (1985), the only important sedimentary rock types that do not show Eu depletion are some first cycle volcanogenic sediments deposited in fore-arc basins of island-arcs and derived mainly from andesites, which are likely to reflect the parent rock patterns. As the oceanic crust descends beneath the island arc, its sediments and volcanic rocks feed the andesitic magmas which, erupting at surface, are deposited in the fore-arc basin. Thus, the Meductic black shales, lacking a positive Eu anomaly, were likely deposited in a relatively quiet back-arc setting.

Lack of evidence of proximal hydrothermal activity is difficult to reconcile with the anomalously high $\mathrm{Ba}$ values. If due to detrital input, then there should be a strong positive correlation of $\mathrm{Ba}$ with $\mathrm{TiO}_{2}$. As there is not, some other mechanism has to be invoked. Considering the good correlation between $\mathrm{Ba}$ and $\mathrm{Si}$ in oceanic sediments (e.g., carbonate-free siliceous oozes; Church, 1979), the incorporation and subsequent dissolution of Ba-enriched silica tests might have provided a source of the $\mathrm{Ba}$ in the Meductic shales. In brief, $\mathrm{Ba}$ could have collected at the sediment surface along with biological debris, have been absorbed on clay minerals (Krauskopf, 1955), or somehow have been ponded at the base of a stagnant restricted basin (MacIntyre, 1992). MacIntyre (1992) observed that the restricted basins that may result from basin subsidence provide favourable sites 


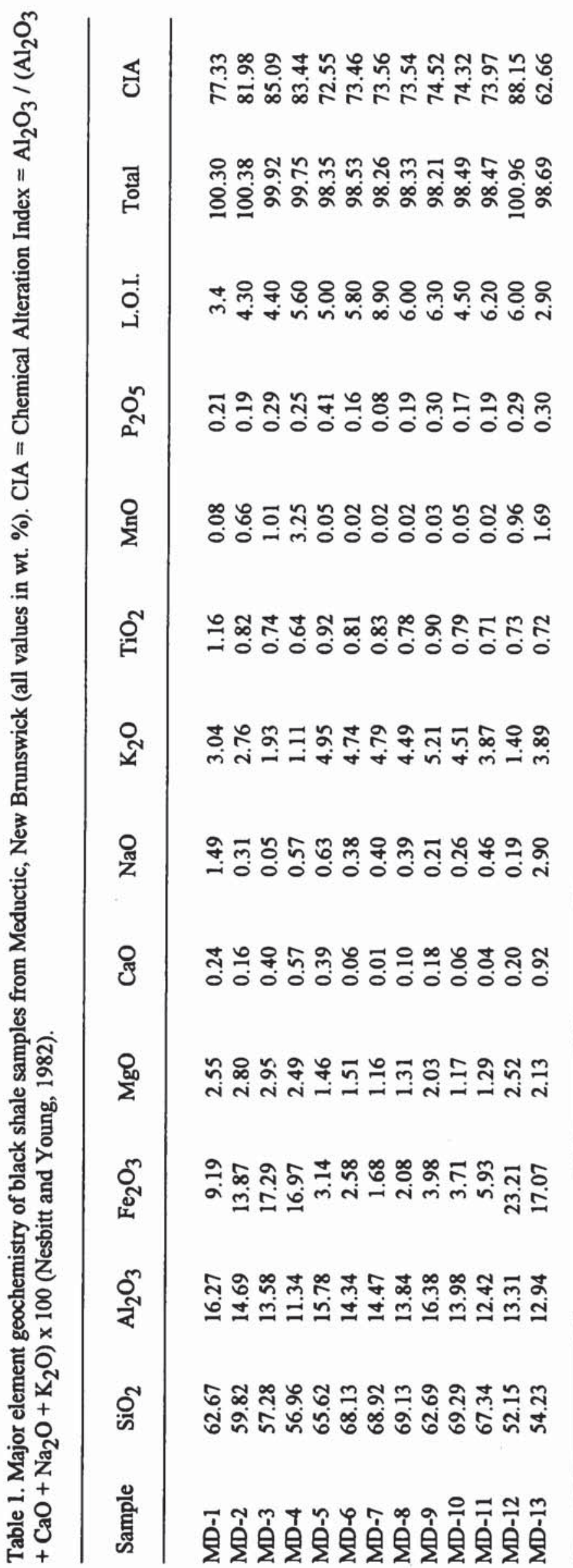

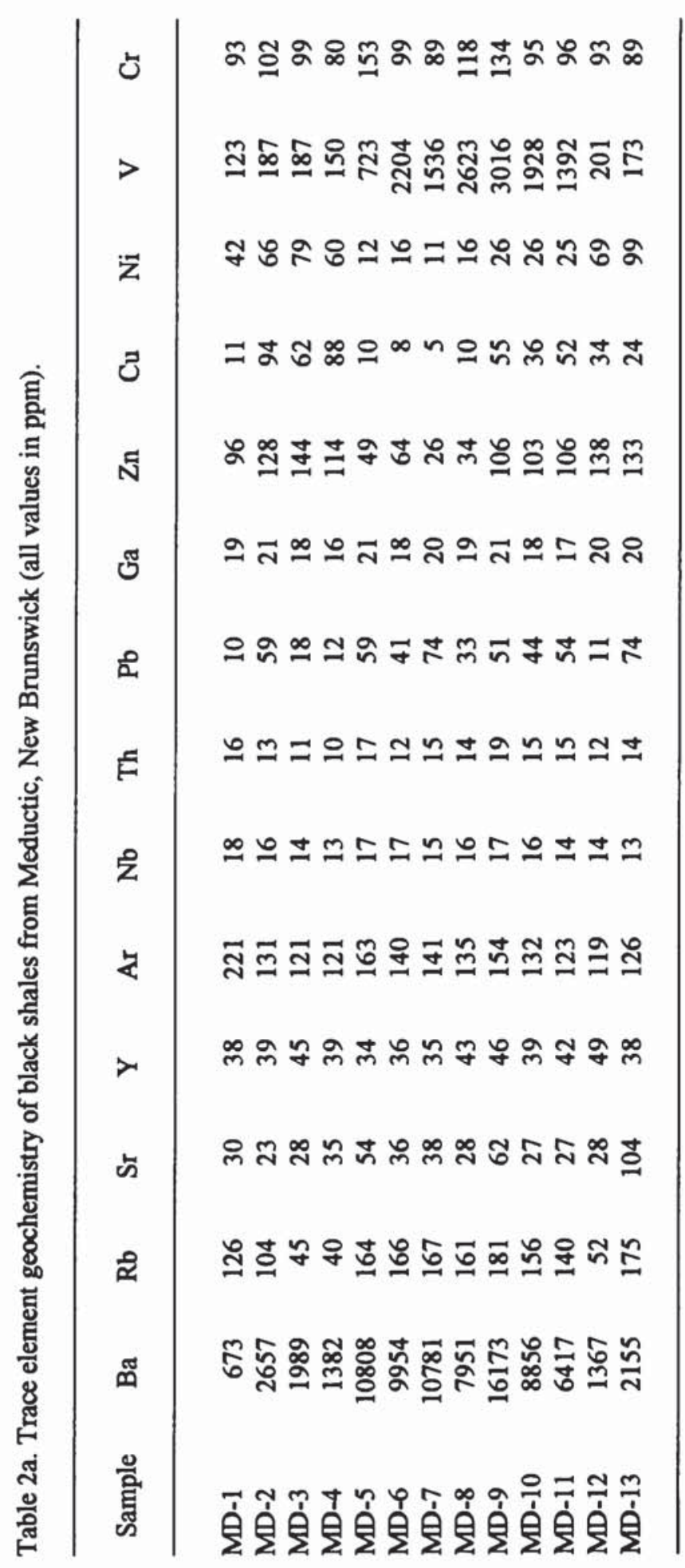

for the ponding of exhaled Ba-enriched brines. Support for this last mechanism occurs in the correlation of $\mathrm{V}$ with $\mathrm{Ba}$ (see Fig. 4f). Vanadium is most effectively fixed in sediments in association with organic compounds (e.g., porphyrins) when competing metals, particularly $\mathrm{Ni}$, are removed from anoxic pore waters as sulfide complexes (Arthur and Sageman, 1994). Indications are that something like this may have occurred, as suggested by the antipathetic behaviour of these two metals (see Fig. 4e, f). 
Table 2b. Rare earth element geochemistry (REE) of black shales from Meductic, New Brunswick. BBB-1,2,3 after Fyffe and Pickerill (1993) (all values in $\mathrm{ppm}$ ).

\begin{tabular}{lrrrrrr}
\hline Sample & MD-2 & MD-5 & MD-9 & BBB-1 & BBB-2 & BBB3 \\
\hline La & 54.74 & 43.72 & 51.71 & 46.87 & 44.11 & 42.89 \\
Ce & 140.47 & 94.69 & 108.95 & 98.95 & 92.37 & 92.37 \\
Nd & 48.74 & 48.84 & 56.69 & 47.65 & 43.29 & 43.78 \\
Sm & 9.57 & 8.30 & 10.15 & 9.03 & 8.41 & 8.60 \\
Eu & 2.01 & 1.39 & 1.64 & 1.63 & 1.45 & 1.51 \\
Tb & 1.33 & 1.02 & 1.20 & 1.11 & 1.05 & 1.10 \\
Yb & 3.84 & 3.59 & 4.40 & 4.30 & 4.09 & 3.84 \\
Lu & 0.56 & 0.55 & 0.69 & 0.62 & 0.59 & 0.60 \\
Hf & 3.80 & 4.33 & 4.03 & 3.99 & 3.92 & 3.73 \\
Ta & 13.09 & 14.63 & 16.74 & 1.36 & 1.22 & 1.24 \\
U & 3.68 & 11.64 & 21.58 & 14.71 & 14.64 & 16.67 \\
Sc & 15.65 & 16.04 & 16.40 & 15.90 & 14.19 & 14.01 \\
Co & 34.53 & 1.22 & 1.98 & 0.88 & 0.75 & 5.35 \\
& & & & & & \\
\hline & & & & & &
\end{tabular}

Table 3. Carbon and sulfur analyses of four selected black shale samples from Meductic, New Brunswick (all values in wt. \%).

\begin{tabular}{lccrrrr}
\hline Sample & $\begin{array}{c}\text { Total } \\
\text { Carbon }\end{array}$ & Sulfur & $\begin{array}{c}\text { Organic } \\
\text { Carbon }\end{array}$ & $\begin{array}{c}\text { Residual } \\
\text { Carbon }\end{array}$ & $\mathrm{CO}_{2}$ & $\mathrm{SO}_{4}$ \\
\hline MD-1 & 1.05 & 0.02 & 0.05 & $<0.01$ & $<0.03$ & 0.02 \\
MD-2 & 0.17 & 0.01 & 0.16 & $<0.01$ & $<0.03$ & 0.01 \\
MD-5 & 1.74 & 0.15 & 1.76 & $<0.01$ & $<0.03$ & 0.13 \\
MD-9 & 2.35 & 0.21 & 2.28 & 0.02 & 0.15 & 0.17 \\
\hline
\end{tabular}

Table 4. Mineralogical composition of four selected Meductic black shale samples as determined by X-ray diffraction methods.

\begin{tabular}{lccccc}
\hline Sample & Muscovite & Clinochlore & Kaolinite & Plagioclase & Quartz \\
\hline MD-1 & $\mathbf{X}$ & $\mathbf{X}$ & & $\mathbf{X}$ & \\
MD-2 & $\mathbf{X}$ & $\mathbf{X}$ & & $\mathbf{X}$ & \\
MD-5 & $\mathbf{X}$ & & $\mathbf{X}$ & $\mathbf{X}$ \\
MD-9 & $\mathbf{X}$ & & $\mathbf{X}$ & & $\mathbf{X}$ \\
\hline
\end{tabular}

A back-arc environment seems a reasonable site for accumulation of the Meductic black shales. In this respect the $\mathrm{MnO}$ content is quite informative (Table 1): three of the stratigraphically lowest Meductic shale samples (MD-2, 3, 4) are relatively enriched in $\mathrm{MnO}$ ( 0.66 to $3.25 \mathrm{wt}$. \%). Likewise, samples MD-12 and MD-13 from the overlying Oak Mountain Formation are enriched in $\mathrm{MnO}$ (0.96 and $1.69 \mathrm{wt}$. \%, respectively). These figures indicate that oxic conditions existed at an early stage and recommenced following deposition of the Bright Eye Brook shales.

Strong supporting evidence for the above hypothesis is supplied by the high chemical index of alteration (CIA; Table 1) of the most MnO-rich rocks. The higher numbers reflect a higher degree of weathering of the source rocks. The Ce 

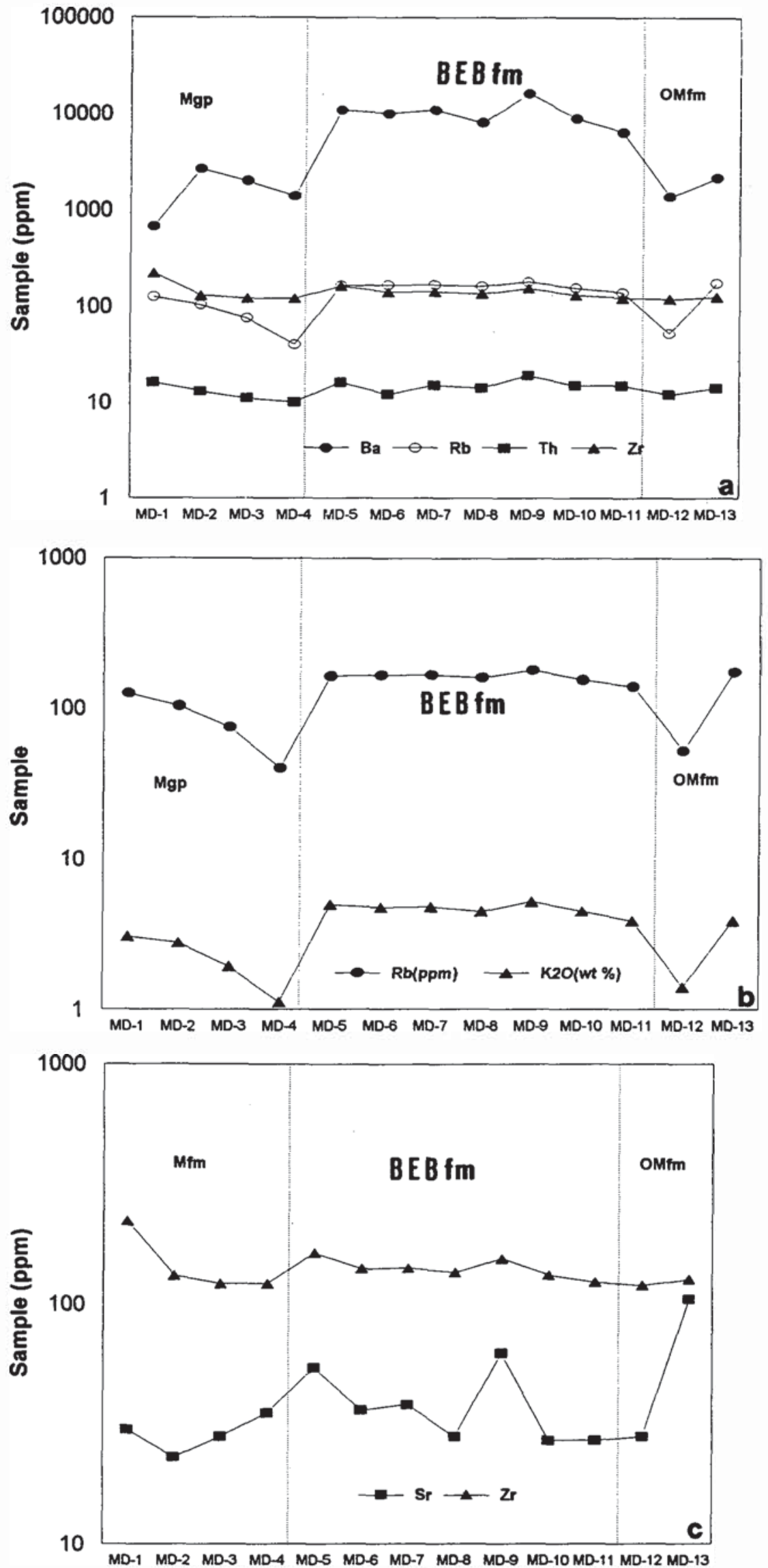

Fig. 4. Elemental concentrations compared in the Miramichi Group (Mgp); Meductic black shales (from which the composition of average Meductic black shale is derived = Bright Eye Brook Formation) (BEBfm); Oak Mountain Formation (OMfm). (a) Ba, Rb, $\mathrm{Th}$, and $\mathrm{Zr}$ (ppm); (b) $\mathrm{Rb}$ and $\mathrm{K}_{2} \mathrm{O}$; (c) $\mathrm{Sr}$ and $\mathrm{Zr}$; (d) $\mathrm{Zr}$, $\mathrm{TiO}_{2}, \mathrm{Nb}$ and $\mathrm{Cr}$, (e) $\mathrm{Ni}, \mathrm{Rb}, \mathrm{Zn}, \mathrm{Fe}_{2} \mathrm{O}_{3}$ and $\mathrm{Ba}$; (f) V, Ba, $\mathrm{Rb}$, and $\mathrm{MnO}$; (g) $\mathrm{SiO}_{2}$ and $\mathrm{Fe}_{2} \mathrm{O}_{3}$ (wt. \%). 

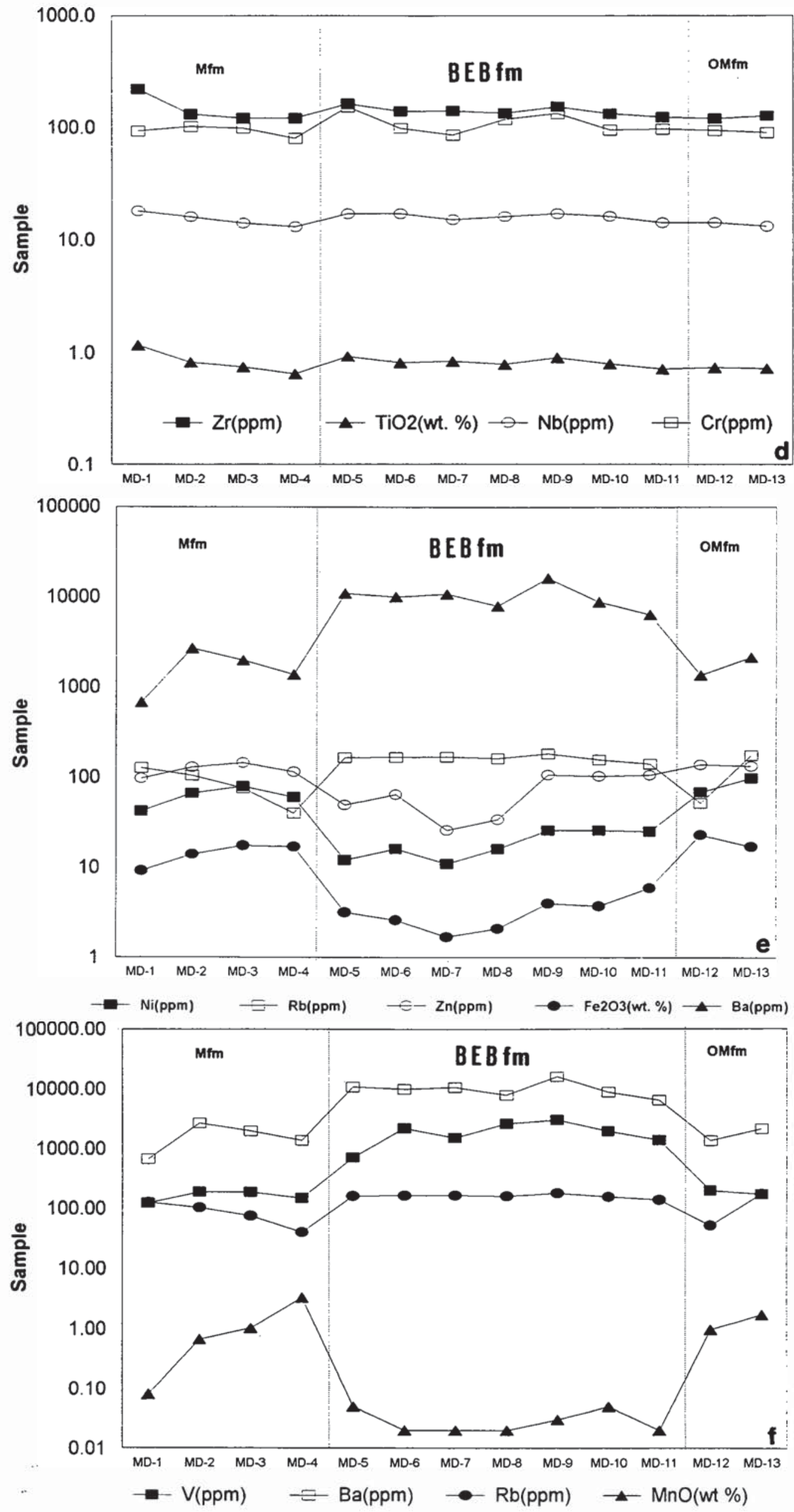

Fig. 4. Continued. 


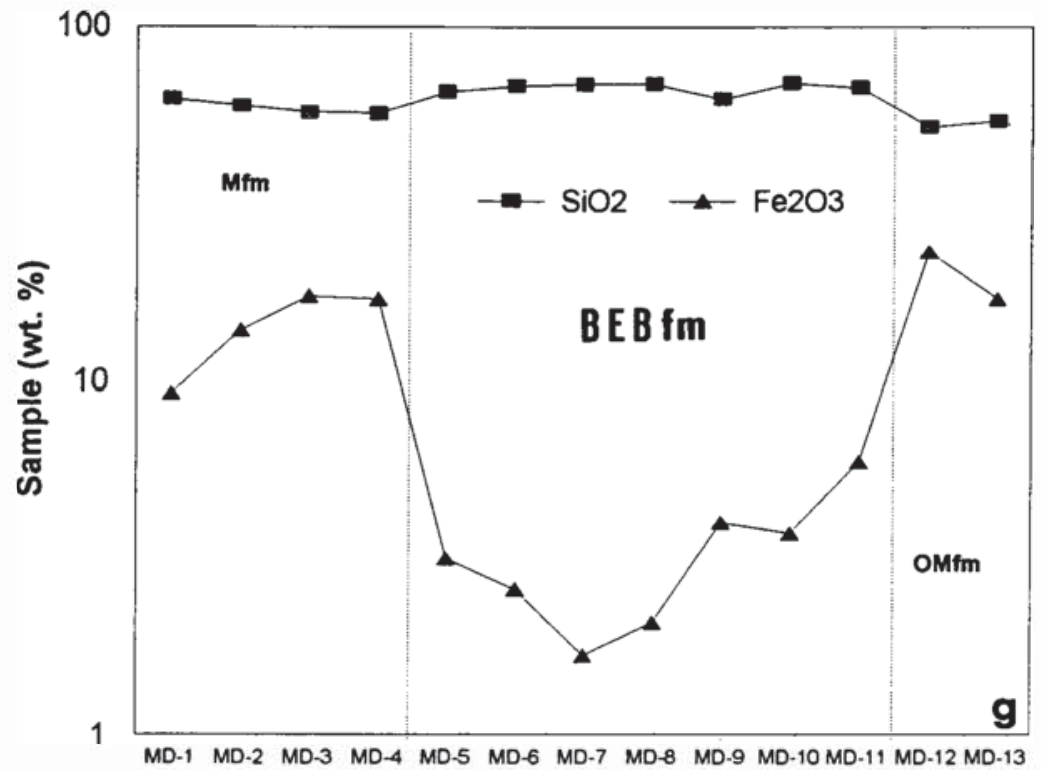

Fig. 4. Continued.

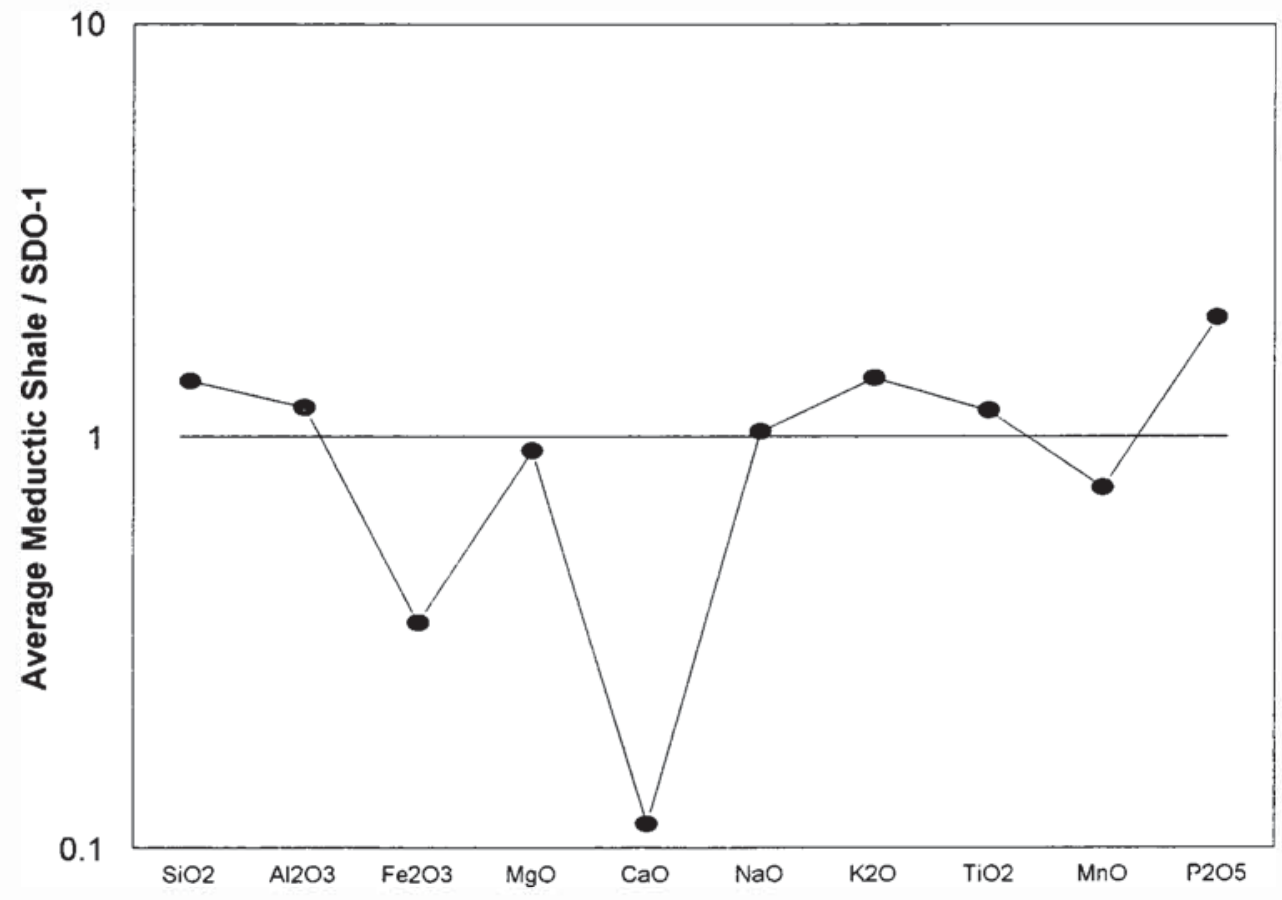

Fig. 5. Major elements composition of the average Meductic black shale normalized to black shale standard SDO-1.

enrichment in MD-2 is an additional reliable indication of early oxygenating conditions. According to McLennan (1989), under oxidizing conditions $\mathrm{Ce}^{3+}$ goes to $\mathrm{Ce}^{4+}$, and in the marine environment (the only place on Earth where this reaction occurs on a large scale) is associated with Mn nodules (see also Murray et al., 1990). Thus, low $\mathrm{MnO}$ and a lack of a positive $\mathrm{Ce}$ anomaly throughout most of the Meductic section substantiates the concept of change from oxidizing to anoxic depositional conditions. Therefore, as a first approximation, the model of MacIntyre (1992) for Ba-enrichment in stagnant basins seems appropriate to explain the metalliferous condition of the Meductic black shales.
Rigorous testing of any hypothetical model to explain the source of metals in the Meductic shale will require extensive analysis of organic matter content and clay minerals (cf. Breit et al., 1989), and will not be attempted here. However, it is instructive to consider briefly whether the anoxic event, as represented by the Meductic metalliferous black shales, can be related to the record of ancient sea level fluctuations. According to this record, as summarized by Stanley (1986), a portion of which is portrayed in Figure 2, sea levels rose from low levels in the early Ordovician, dropped suddenly in the middle Ordovician due to rapid climatic changes, then climbed gradually until late Ordovician when 


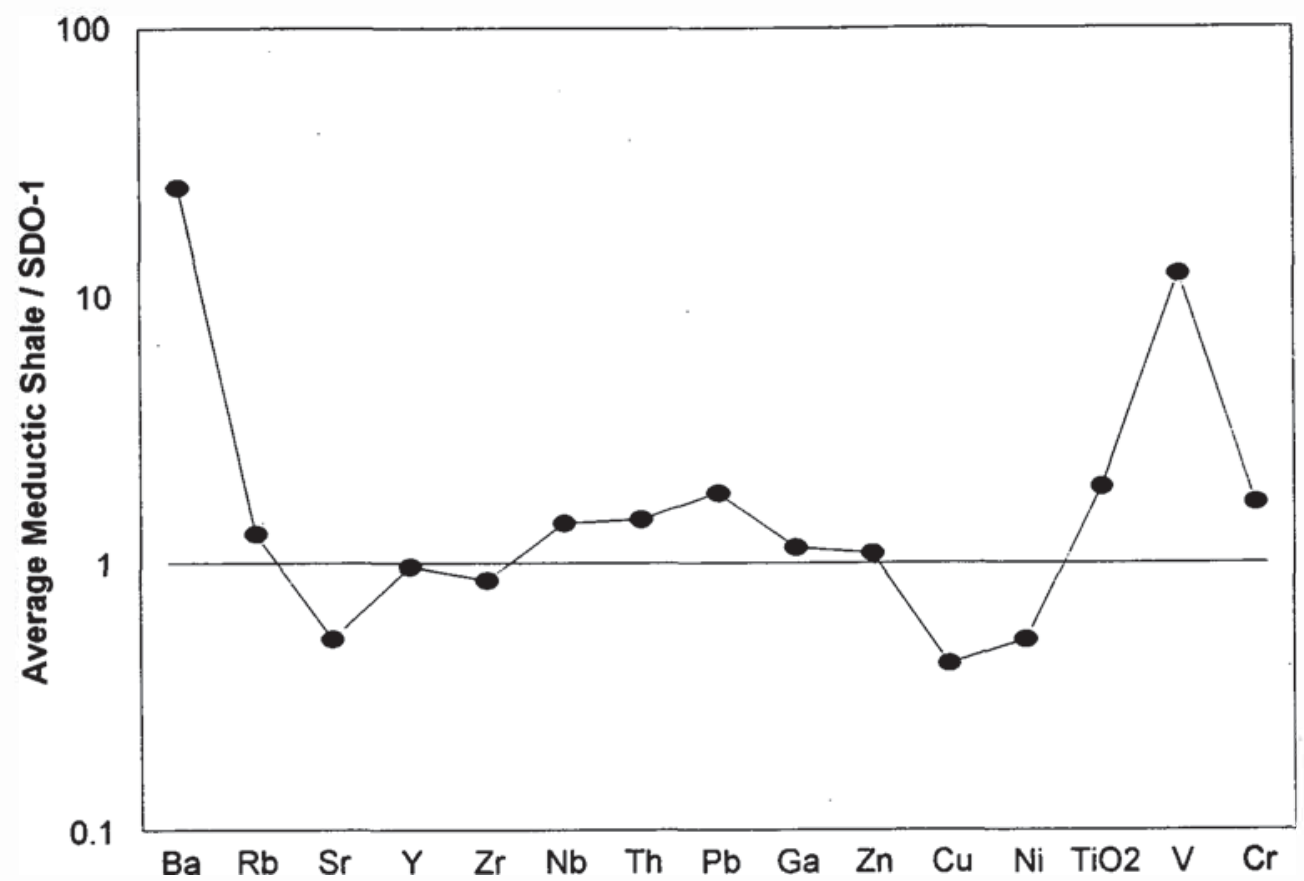

Fig. 6. Trace element composition of the average Meductic black shale normalized to black shale standard SDO-1.

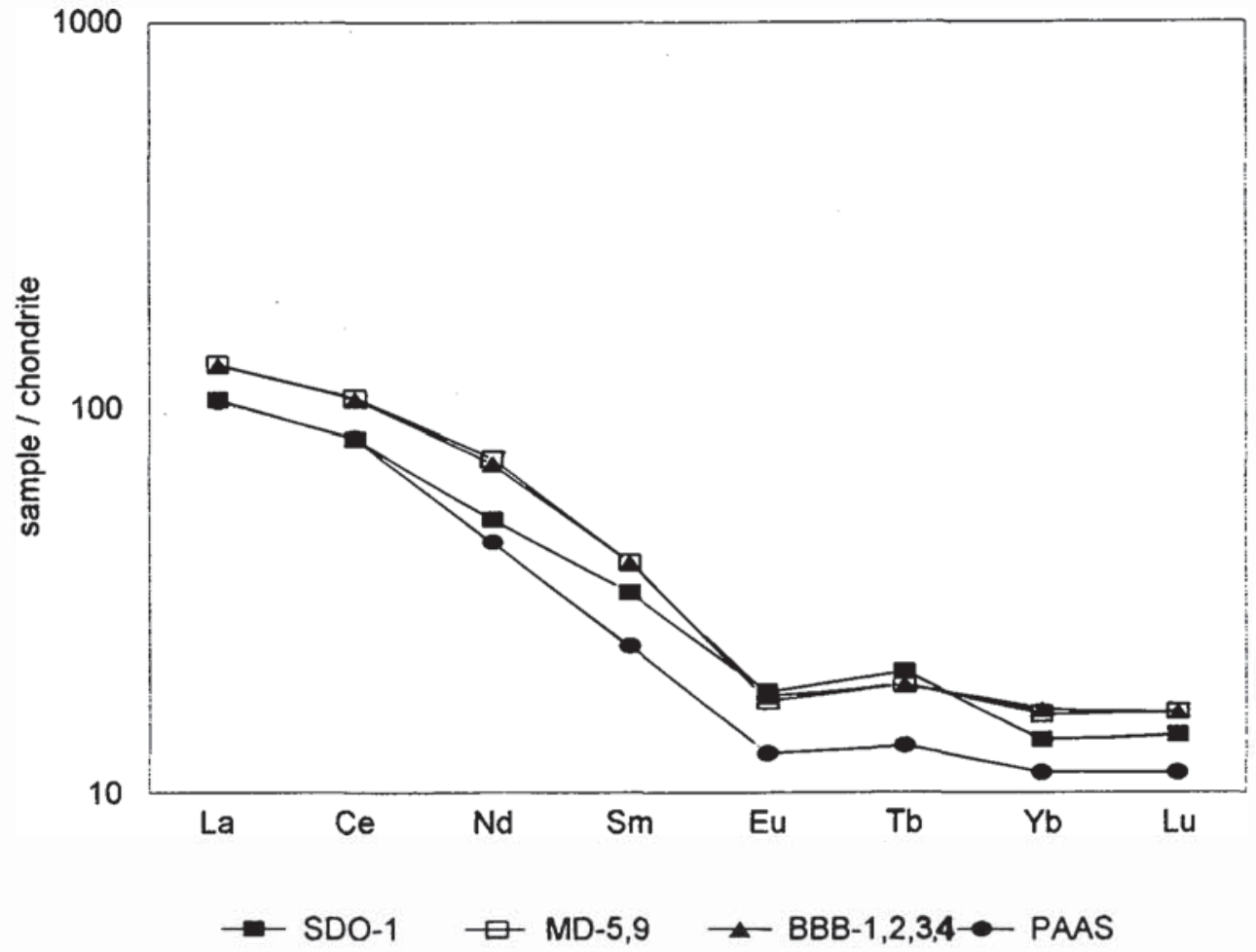

Fig. 7. Chondrite-normalized REE distribution (calculated according to the procedure of Evensen et al., 1978) [Averages of MD-5 and MD-9, this study, and BBB-1,2,3,4 taken from the same locality by Fyffe and Pickerill (1993) compared with PAAS]. BBB samples are virtually coincident with the MD samples.

another sudden drop occurred, accompanied by a major marine extinction.

During anoxic diagenesis, iron is fixed in pyrite and Mn is mobilized toward the sediment-water interface (Force and Cannon, 1988). However, where the Eh of overlying seawater is low enough to support high Mn solubility, an increasing reservoir of dissolved Mn may result. Should precipitation occur, the resulting (distal?) deposits may show evidence of having precipitated at interfaces between deep water of low Eh, and shallow water of high $\mathrm{Eh}$. At Meductic, 


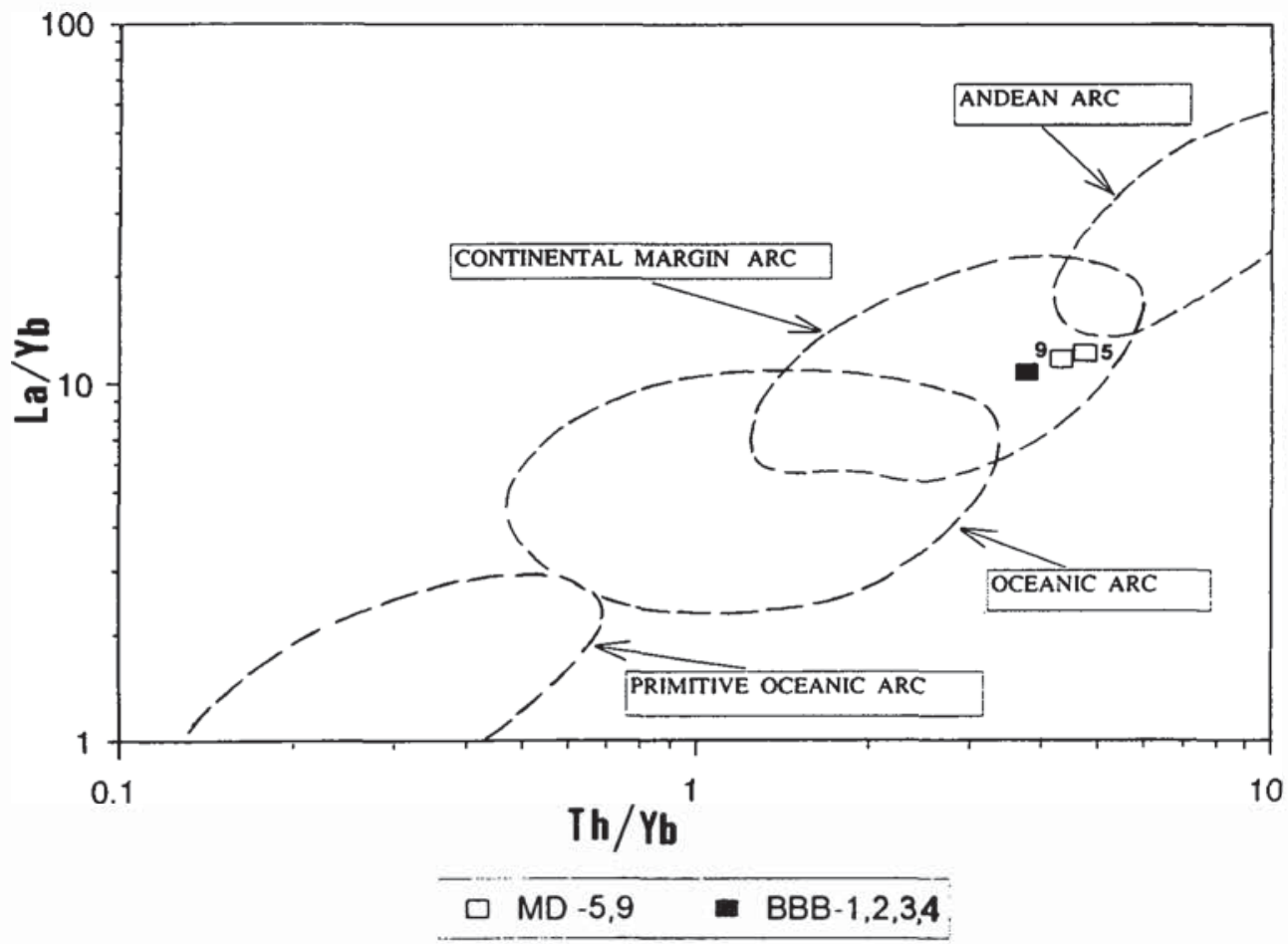

Fig. 8. La/Yb versus $\mathrm{Th} / \mathrm{Yb}$ ratios in selected Meductic black shales with respect to fields of volcanic rocks in an island arc setting (modified from Dostal, 1989). Open rectangles are samples MD-5 and MD-9, this study; closed rectangle is the average of BBB1,2,3,4 (Fyffe and Pickerill, 1993).

the high Mn concentrations in samples MD-2 to MD-4 (Table 1) may represent such sediments deposited in an oxygenated environment. Thus, over this same interval, there is a decrease in $\mathrm{K}_{2} \mathrm{O}$, increase in CIA values, decrease in detrital component ( $\mathrm{Ti}, \mathrm{Zr}, \mathrm{Al}$ ), and $\mathrm{Ce}$ enrichment.

The absence of $\mathrm{Ce}$ fractionation in the grey and black shales of the Patrick Brook Formation and in the black shales of the Pointe Verte and Boucher Brook formations has also been interpreted by Fyffe (1994) to represent deposition in an oxygen-depleted environment. During the early interval of $\mathrm{Mn}$ deposition, the Meductic black shales show initial low $\mathrm{V}$ content, and subsequently, a rise to extremely high values. This is in agreement with an early influx of oxygen and later, a change to anoxic conditions, as evidenced by the elevated values for TOC and sulfur (Table 3 ).

Although high primary production may provide first order control on elevated levels of organic carbon in marine deposits (Pedersen and Calvert, 1990), sea level changes also have been linked to the phenomenon. For example, according to Leggett (1980), preservation of carbon in sediments preferentially occurs during (anoxic) intervals of eustatic transgression. At Meductic, this transgessional interval may have coincided with deposition of sediment (see Table 3) represented by samples MD-5 through MD-10.

\section{Conclusions}

By definition, the Meductic black shales of the Bright Eye Brook Formation qualify as metalliferous as investigated in a measured $50 \mathrm{~m}$ (true thickness) stratigraphic section at the top of the middle Ordovician Tetagouche Group. They were deposited in a back-arc basin associated with an island-arc system formed during early to middle Ordovician with the closing of the proto-Atlantic Ocean and the onset of the Taconic orogeny. Geochemically, they are characterized by elevated $\mathrm{Ba}$ and $\mathrm{V}$ contents, moderate enrichment in $\mathrm{Nb}, \mathrm{Th}, \mathrm{Pb}, \mathrm{Ti}$ and $\mathrm{Cr}$, chondrite-normalized $\mathrm{REE}$ patterns showing elevated LREE and fairly flat HREE, negative $\mathrm{Eu}$ and slightly positive $\mathrm{Ce}$ anomalies, early and late enrichment in $\mathrm{Mn}$, and an intervening $\mathrm{Mn}$ impoverished stratigraphic interval.

The average Meductic black shale, as deduced from analyses of samples of the Bright Eye Brook Formation, is distinguished from the underlying Miramichi Group and the overlying Oak Mountain Formation by chemostratigraphic changes, including relative impoverishment in $\mathrm{MnO}, \mathrm{Fe}_{2} \mathrm{O}_{3}, \mathrm{Ni}, \mathrm{Zn}$ and relative enrichment in $\mathrm{V}, \mathrm{Ba}, \mathrm{Rb}, \mathrm{K}_{2} \mathrm{O}$ and $\mathrm{P}_{2} \mathrm{O}_{5}$. The favoured model to account for the elevated $\mathrm{Ba}$ content of the average Meductic black shale is one that allows enrichment to occur in a restricted, anoxic basin due to convective circulation of barium-rich brines. The mechanism of this circulation may be linked to elevated heat flow generated by regional tectonic activity during the closing of the protoAtlantic Ocean.

Deposition at the top of the Miramichi Group occurred in an oxic environment (high $\mathbf{M n}$ ). This was succeeded in the Bright Eye Brook Formation by an interval of stagnation (increased V and B and lowered Mn contents) terminated by a return to oxic conditions in the overlying Oak Mountain Formation. This pattern is compatible with that of postulated sea level fluctuations in the early Paleozoic (specifically the gradual rise in sea level during the late Ordovician). 


\section{ACKnowledgements}

Don Hattie of Geosleuths, Sackville, and Les Fyffe, of the Minerals and Energy Division, Department of Natural Resources and Energy, Fredericton, New Brunswick, provided valuable advice and discussion during preparation of this paper. D.V. Venugopal and L.R. Fyffe kindly provided several rock samples for comparison. We are grateful too, for the constructive criticism by journal referees J. Dostal and L.R. Fyffe that resulted in substantial improvements to the manuscript. Financial support was provided by the Natural Sciences and Engineering Research Council grant A8295 to DJM.

Arthur, M.A. and Sageman, B.B. 1994. Marine Black Shales: Depositional mechanisms and environments of ancient deposits. Annual Review, Earth and Planetary Sciences, 22, pp. 499-551.

Breit, G.N., WANTY, R.B., and Tuttle, M.L. 1989. Geochemical control on the abundance of vanadium in black shales and other carbonaceous rocks. U.S. Geological Survey, Circular 1058, (IGCP Project 254), pp. 1-5.

CHURCH, T.M. 1979. Marine barite. Mineralogical Society of America, Reviews in Mineralogy, Marine Minerals 6, pp. 175-209.

Dostal, J. 1989. Geochemistry of Ordovician volcanic rocks of the Tetagouche Group of southwestern New Brunswick. Atlantic Geology, 25, pp. 199-209

Evensen, N.M., Hamilton, P.J., and O'Nions, R.K. 1978. Rare earth abundances in chondritic meteorites. Geochimica et Cosmochimica Acta, 42, pp. 1199-1212.

ForCE, E.R. and CANNON, W.F. 1988. Depositional model for shallow marine manganese deposits around black shale basins. Economic Geology, 83, pp. 93-117.

FYFFe, L.R. 1982. Taconian and Acadian structural trends in central and northern New Brunswick. In Major Structural Zones and Faults of the Northern Appalachians. Edited by P. StJulien and J. Beland. Geological Association of Canada, Special Paper 24, pp. 117-130.

-...- (Editor) 1990. Field Guide to Massive Sulfide Deposits in Northern New Brunswick. Base Metal Symposium, New Brunswick, 1990. New Brunswick Department of Natural Resources and Energy, Minerals and Energy Divison, 162 p.

-1994. A note on the geochemistry of some shales from the Bathurst-Newcastle Mining Camp, northern New Brunswick. Atlantic Geology, 30, pp. 143-151.

FyfFe, L.R. and PICKERILL, R.K. 1993. Geochemistry of upper Cambrian-lower Ordovician black shale along a northeastern Appalachian transect. Geological Society of America Bulletin, 105, pp. 897-910.

FyfFe, L.R., Forbes, W.H., and RIVA, J. 1983. Graptolites from the Benton area of west-central New Brunswick and their regional significance. Marine Sediments and Atlantic Geology, 19, pp. 117-125.

Fyffe, L.R., van StaAl, C., and Winchester, J.A. 1990. Late Precambrian-early Paleozoic volcanic regimes and associated massive sulfide deposits in the northeastern mainland Appalachians. Canadian Institute of Mining and Metallurgy Bulletin, 83(938), pp. 70-78.

GARIEPY, C. and David, J. 1988. Lithogeochemistry of the lower Tetagouche Group in the Woodstock area, central New Brunswick. 13th Annual Review of Activities, Project Resumes: Information Circular 88-2, New Brunswick Minerals and Energy
Division, Department of Natural Resources and Energy, 145 p.

Goodfellow, W.D., Peter, J.M., and Lentz, D.R. 1995. Geological setting and genesis of the giant Brunswick No. 12 massive sulfide deposit, Bathurst Mining Camp, New Brunswick. Programme with Abstracts, Geological Association of Canada, Mineralogical Association of Canada, May 17-19, Victoria, British Columbia, p. A37.

Hennessy, J.F. 1995. Geochemistry of Ordovician black shales near Meductic, New Brunswick. B.Sc. thesis, Mount Allison University, Sackville, New Brunswick, 56 p.

HuYCK, H.L.O. 1990. When is a Metalliferous black shale not a black shale? Metalliferous Black Shales and Related Ore Deposits, Proceedings, 1989 United States Working Group Meeting, International Geological Correlation Program Project 254, United States Geological Survey, Circular 1058, pp. 42-56.

KRAuSKopf, K.B. 1955. Sedimentary deposits of rare metals. In Part I of Economic Geology, 50th anniversary volume, 1905 . 1955. Edited by A.M. Bateman. Economic Geology Publishing Company, Urbana, Illinois, pp. 411-463.

Leggett, J.K. 1980. British lower Palaeozoic black shales and their palaeo-oceanographic significance. Journal of the Geological Society of London, 137, pp. 139-156.

LentZ, D.R. and Goodfellow, W.D. 1995. Petrology, geochemical composition, and depositional environment of felsic volcanic and related sedimentary rocks from the Brunswick belt, Bathurst Mining Camp, New Brunswick. Programme with Abstracts, Geological Association of Canada, Mineralogical Association of Canada, May 17-19, Victoria, British Columbia, p. A.43.

MacIntYre, D.G. 1992. Geological setting and genesis of sedimentary exhalative barite and barite-sulfide deposits, Gataga District, Northern British Columbia. Exploration and Mining Geology, 1(1), pp. 1-20.

MCBRIDE, D.E. 1976. Tectonic setting of the Tetagouche Group, host to the New Brunswick polymetallic massive sulphide deposits. Geological Association of Canada, Special Paper No. 14 , pp. $473-485$.

McLennan, S.M. 1989. Rare Earth Elements in Sedimentary Rocks: Influence of Provenance and Sedimentary Processes. In Geochemistry and Mineralogy of Rare Earth Elements. Edited by B.R. Lipin and G.A. Mckay. Reviews in Mineralogy, 21, pp. 169 200.

Murray, R.W., Buchholtzten Brink, M.R., Jones, D.L., Gerlack, D.C., and Russ III, G.P. 1990. Rare earth elements as indicators of different marine depositional environments in chert and shale. Geology, 18, pp. 268-271.

Nesbitt, H.W. and Young, G.M. 1982. Early Proterozoic climates and plate motions inferred from major element chemistry of lutites. Nature, 199, p. 715.

Neuman, R.B. 1984. Geology and paleobiology of islands in the Ordovician Iapetus Ocean: review and implications. Geological Society of America Bulletin, 95, pp. 1188-1201.

Pedersen, T.F. and Calvert, S.E. 1990. Anoxia vs. productivity: what controls the formation of organic-carbon rich sediments and sedimentary rocks? American Association of Petroleum Geologists Bulletin, 74(4), pp. 454-466.

Reichenbach, I. 1993. Black shale as an environmental hazard: a review of black shales in Canada. Geological Survey of Canada, Open File 2697, 62 p.

Shultz, R.B. 1991. Metalliferous black shales: accumulation of carbon and metals in cratonic basins. Society of Economic Geologists, Reviews in Economic Geology, 5, pp. 171-176. 
Stanley, S.M. 1986. Earth and Life Through Time. W.H. Freeman and Company, New York, 690 p.

TAYLOR, S.R. and MCClenNAN, S.M. 1985. The Continental Crust: its Composition and Evolution. Blackwell Scientific Publications, $312 \mathrm{p}$.

van StAAL, C.R. and FyFFe, L.R. 1991. Dunnage and Gander zones, New Brunswick: Canadian Appalachian region. New Brunswick Department of Natural Resources and Energy, Mineral Resources Geoscience, Report 91-2, 39 p.

Venugopal, D.V. 1979. Geology of Debec Junction-Gibson Millstream-Temperance Vale-Meductic Region. Map Report 79 5, Mineral Resources Branch, Department of Natural Resources, New Brunswick, 36 p.

Whitehead, R.E.S. and Goodfellow, W.D. 1977. Geochemistry of volcanic rocks from the Tetagouche Group, Bathurst, New Brunswick, Canada. Canadian Journal of Earth Sciences, $15(2)$, pp. 207-219.

\section{Appendix A: \\ REPRESENTATIVE SAMPLE DESCRIPTIONS}

\section{MD-1 (Miramichi Group)}

Dark grey shale, average grain size $<0.04 \mathrm{~mm}$, well bedded on a scale of 0.1 to $0.4 \mathrm{~mm}$. Micro-scale relict sedimentary structures include cross-bedding and the sporadic presence of spherules (to $1 \mathrm{~mm}$ diameter) consisting of many tiny rounded siliceous grains of quartz, chlorite and lesser clays. Bedding plane lamination well preserved despite a moderately strong foliation which cuts obliquely across bedding. Like the groundmass phyllosilicates, accessory grains of evenly disseminated weakly martitized ilmenite show preferred alignment in the plane of foliation.

\section{MD-2 (Bright Eye Brook Formation)}

Dark grey shale, bedding contorted about $1 \mathrm{~cm}$-diameter ferruginous concretions scattered sporadically throughout the siliceous matrix. The concretions are basically aggregates of floating and/or interconnected spherules (avg. $0.1 \mathrm{~mm}$ diameter) composed of about equal portions of complexly intergrown limonite and (well crystallized) hematite. A few traces of pyrite and chalcopyrite remain of what at some earlier stage may have been essentially pyritic concretions. Concretions here comprise approximately $10 \%$ of the sample. Numerous veinlets of iron oxide (to a maximum width of 2 $\mathrm{mm}$ ) traverse the sample sub-parallel to foliation.

\section{MD-5 (Bright Eye Brook Formation)}

Dark grey siltstone with ca. $5 \%$ fine sandstone present as lenticles averaging $0.4 \mathrm{~mm}$ wide $\times 4 \mathrm{~mm}$ long. Individual grains in the sandstone are sub-angular and include quartz, well-twinned plagioclase (andesine), illitic (muscovite?) mica and trace amounts of accessory K-feldspar. Heavy minerals are notably lacking in these relatively coarse grained lenticles, but hematite, rutile and pyrite occur lightly disseminated throughout the finer grained (brown) chlorite-enriched groundmass. Accessory amounts of a moderately high reflectance graphitized bitumen occur in the groundmass, suggesting that this rock may have served as a source of liquid hydrocarbons early in its history.

\section{MD-9 (Bright Eye Brook Formation)}

Organic-rich black shale lacking bedding plane lamination contains scattered euhedral pyrite porphyroblasts to $1 \mathrm{~mm}$ diameter. Pyrite shows only incipient replacement by limonite. Accessory amounts of moderately to highly reflecting graphitized bitumen are confined to the shale. Much of this sample consists of a recrystallized mosaic of quartz, minor plagioclase and patches of clay together with scattered tiny crystals of titanaugite, implying a certain volcanogenic component.

\section{MD-13 (Oak Mountain Formation)}

Light red-brown iron formation, banded on a centimeter scale, but otherwise lacking a distinct fabric. Euhedral magnetite crystals to $0.05 \mathrm{~mm}$, some thinly rimmed with hematite, make up from 10 to 12 modal percent of the sample. Additionally, a liberal sprinkling of tiny (average diameter 0.005 $\mathrm{mm}$ diameter) blebs of hematite are scattered throughout a microcrystalline silicate groundmass comprised of about equal amounts of plagioclase, quartz, muscovite and chlorite. Several veins $(<0.05 \mathrm{~mm}$ wide) of well crystallized hematite traverse the slide. These are intermingled with numerous even smaller anastomosing veinlets of marcasite, and scattered rounded patches of the same material, all of which are altered in varying degree to limonite. 